\title{
ISSUES IN HUMAN RIGHTS: THE PLIGHT OF MUSLIM MINORITIES AND THE LESSONS THEREIN FOR MUSLIM MAJORITIES
}

\author{
Hikmatullah Babu Sahib* and Asiah Binti Yaacob**
}

\begin{abstract}
The plight of non-Muslims or other minority communities within a Muslim majority country has been much debated under the broad topic of human rights. Yet problems relating to Muslim minorities in non-Muslim polities have yet to be adequately addressed. More should be done to educate the large Muslim world on the plight of these minority Muslim communities. The lack of focus on the fate of such minorities had resulted in their being subjected to unfair treatment or oppression, painful misery, and unfriendly policies of containment or integration. The authors export other more subtle forms of subjugation more serious than overt oppression and violence. Muslims in adverse minority settings have always struggled to maintain a proper balance between sustaining their religious identity and obligations and maintaining loyalty towards their country. We examine several issues in the light of established human rights principles and identify practical challenges faced in translating these ideals into reality.
\end{abstract}

\section{Introduction}

One of the core aims of Islam is "to create a society based on a deep sense of moral responsibility and justice in order to preserve human dignity accorded to man by God". . Furthermore, "without the practical recognition of the basic rights of man all talk of human dignity will remain empty verbiage"2. Therefore, Muslims believe that the basic duty of a state or a political entity is to protect the rights and dignity of its citizens, wards and subjects. Citizens' duties in this respect are also seen as another aspect of rights, since both rights and duties are like the two wings of a bird which sustains the stability of a society in flight.

Among the basic duties of a society in respect of human dignity is to guarantee them adequate food, drink, clothing, lodging, education and employment as well as grant them an undeniable right to express their opinion; to practice religion to the best of their knowledge and ability; to participate in the political life of their country, and to be assured of their own security and that of their family and kin. Many countries have however fallen short in conforming to these rights of humans and duties of states in keeping to their constitutional pledges according to humans the freedom to practice religious rites and express its doctrines. In particular, Muslims living as minorities are known to be subjected to many untold miseries when their rights are systematically usurped or denied under numerous pretexts, the latest of which is the false alarm of terrorism. 
'Muslim minority' is a term applied to that segment of "a population identified for Muslim denomination by virtue of its heritage, faith, customs and history and is subjected to differential treatment for this reason". "If a Muslim denomination in a given society is not subject to such differential treatment on the basis of its heritage, faith, custom and history it may not be termed as Muslim minority, since they are free from discrimination. This definition is definitely a further specification of the literal meaning of the socio-political term minority, which means: "a group of people in a country different from the rest in race or religion". ${ }^{4}$ This means any group of people in a given country who are either different from the rest of the population in respect of [a] religion or [b] race or [c] religion and race together are considered as minority. This should not create any problem if the minorities are taken as equals without any discrimination; problems only arise when they are discriminated on account of their race and religion.

Here we examine several human rights issues having a direct bearing on minorities in general and minority Muslims in particular, in which they are subjected to discriminatory treatment. To analyse Muslim minority issues we review the following topics:

1. Human Rights Issues and Islam

2. A General Sociological Framework for Minority-Majority Relations

3. The Muslim Dilemma: A study of Muslim Minority situations

4. The Responsibility of Muslim Majorities

This framework is not restrictive since it is difficult to isolate any one sector exclusively. The countries selected as examples for understanding the dynamics of the Muslim minority situation are by no means exhaustive. Their selection was based on essential distinctions in respect of state approaches towards minority Muslim subjects. Despite their differences in emphasis, there is an undeniable uniformity when it comes to subjecting minority Muslims to conform to the unfair dictates of the state. This often brings Muslims into direct conflict with the state, and also raises questions about human rights issues in subjugating them and denying their religious freedom.

\section{Human Rights Issues and Islam}

Human rights or the rights of humans is nothing new to Islam. A careful impartial historical study shows that Islam was the first to accord and guarantee personal rights and freedoms for religious minorities. Thus Muslims in principle have no problem with human rights, both as grantors and grantees. The Qur'an addresses this issue in a number of verses where the universality of humanity is stressed by underlining God's favours to man provided to man as an act of benevolence. While commenting on the UDHR, Tabandeh observes that "it does not guarantee 
all the longings of mankind" and that it "has not promulgated anything that was new nor inaugurated innovations. Every clause of it, indeed every valuable regulation needed for the welfare of human society ever enacted by the lawgivers, already existed in a better and more perfect form in Islam"s. He rightly feels that "Islam is the summit and nothing excels it". ${ }^{6}$

Islam defines human rights as those rights which all human beings ought to have because they are so deeply rooted in our humanness that their denial or violation is tantamount to a negation or degradation of that which makes us human. The 'ulamā' regarded human rights as an integral part of faith. Thus, "a man cannot be considered religious in the true sense of the word if he does not grant the rights of his fellowmen. The measure of judging a man's religiosity is how he deals with people, and not how much he prays". ${ }^{7}$ In his essay "Human Rights in Islamic Perspective" Abdul Aziz Said states:

Human rights are concerned with the dignity of the individual - the level of self-esteem that secures personal identity and promotes human community. While the pursuit of human dignity is universal, its forms are designed by the cultures of people. Politics is a cultural activity reflecting tradition and environment. The debate on human rights assumes that in spite of the differences that characterise the spectrum of world cultures, political conduct can be conceptualised by certain common norms and attitudes. In the modern global system Westerners have concentrated on discovering common denominators rooted in Judeo-Christian traditions and from which a calculus of human rights would emerge. This emphasis on Western common denominators projects a parochial view of human rights that excludes the cultural realities and present existential conditions of Third World societies. ${ }^{8}$

Obviously not all aspects in the UDHR are in agreement with Islam. A few specific articles are actually at variance with Islamic Law as commonly interpreted among Muslims. This includes the freedom of changing and choosing one's belief and the problem of a Muslim (particularly a Muslim woman) marrying a polytheist, an idolater or an infidel. In responding to Article 18 which states that an individual has the right to freedom of thought, conscience and religion, Tabandeh says they are only acceptable within the framework of Islamic Law and are consistent with its teachings9. Hence, "no one's freedom gives him the right to blaspheme or to curse God, His Prophets or His saints. Whosoever commits this sin is liable to punishment". ${ }^{10}$ Commenting on problems Muslims face regarding UDHR, Fathi Osman observes they are related to certain general conceptual matters that have not been settled in the Muslim mind, and which may have implications not only in the area of human rights, but in other areas as well. ${ }^{11}$ 
The fundamental problem Muslims confront with UDHR is the question of the supremacy of whose law: divine or man-made? Muslims feel that the rights as articulated in the UDHR are the results largely of the handiwork and agenda of imperial and colonial forces to dictate, advance and protect their own interests. This is reflected inter alia in the composition of its constituent members and the degree of power they wielded. There is a disproportionate representation of the rights of those mighty and strong, which do not fairly reflect the universality of human rights to all other peoples. These unethically imposed man-made rights could never safeguard the varied legitimate interests of the world's underprivileged masses including those of the bulk of the Muslims. Human rights encompasses and is embedded in many inter-related issues including the following prominent topics of loyalty, nationalism, integration, freedom, and equality. We now examine each one in more detail.

Loyalty is defined as being "faithful to one's sovereign, government or country". This definition assumes that loyalty to one's leaders is the same as being loyal to one's country. What is not clear is whether such a loyalty can be held at the expense of one's cherished convictions, particularly if those beliefs were to contradict or contravene the demands and dictates of loyalty. In this regard, Muslims living as minorities the world over face great challenges. They are often subjected to unjust victimisation and marginalisation in terms of education and employment opportunities. Their loyalty to the state is often put to continual tests either deliberately or with various pretexts. This is particularly true in a Muslim minority country which engages in a declared or undeclared war of attrition with a Muslim majority country or territory for its continued survival, even while acting to maintain cordial relationship with it. In such a situation the Muslims in that minority country are faced with the dilemma of having to support "their" national interest against the ummah's interest. Frequently they end up being used as bait or pawns in such bilateral relations. This puts not only the Muslim minorities in jeopardy but also sympathetic Muslim majority countries. Any assistance from Muslim majority countries to improve the lot of the suppressed minority Muslims is viewed with contemptuous suspicion and taken as evidence of meddling in the internal affairs of that Muslim-minority country. This 'loyalty trap' is often used to unfairly deny the Muslims in these minority countries equal rights - cowed down and suppressed if not also oppressed. What these Muslim minority countries fail to notice is that by relegating their Muslim subjects to the periphery of their national lives, they are directly contributing to the creation and incubation of terrorists and extremists among their own Muslims.

The leadership of Muslim-minority countries should begin to accommodate Muslims as they naturally are, without penalising them for simply being different from other citizens, since such unjust treatment clearly violates the basic human 
right of freedom of religion, which every decent country on earth claims to accord to its citizens. Furthermore, these Muslim-minority countries must take cognisance of the sensitivities of their otherwise loyal Muslim population by not establishing too close a relation with openly anti-Islamic countries that are in constant war with Muslims. For example, their supporting countries like Israel despite its blatant violation of basic human rights, will logically earn them the distrust, hatred and consequent disloyalty of their own Muslim community. However, this logical response is sometimes disturbed when certain Muslim countries themselves are establishing closer and stronger relations with Israel. What is recommended here is that these Muslims should select a path or a peaceful way that does not needlessly compromise either genuine national interests or their religious obligations.

While pursuing their religious obligations which might be in conflict with national interests, Muslims in minority situations must never resort to violence to drive home their grievances, for violence begets violence. Instead, they must explore all legal means to take the governments of the day to task for betraying their loyally advanced trust and to make their dissenting voices heard and for their actions to speak in lawful ways. In articulating their views and grievances with responsible and civilised action, this requires at a minimum an educated Muslim population. Unfortunately this remains a sad rarity in most Muslim-minority situations. This is the case because most minority Muslims are being suppressed through numerous educational and employment schemes designed to maintain the existing socio-political status quo. Yet there is hope for minority Muslims, as countries that have technocratically-planned social engineering have miserably failed to transform all their citizens into equally-productive assets, and forced them to draw in foreign talent who are put on a fast tract to acquire citizenship. In many instances these imported workers are used as convenient covers to increase the non-Muslim population through biased selection that further reduces the Muslim minority to greater insignificance. As Muslims are kept under-educated or uneducatable, they become easy targets of unemployment, a situation which in turn alienates them and eventually relinquishes them to ghettos. Welfare assistance through various ostensibly self-help programs will not help in gaining the loyalty of the Muslim community. Government efforts, no matter how sincere they may have intended to be, are more often than not viewed by Muslims as failing to treat Muslims as equally-valued citizens in their respective countries.

Nationalism may be defined as "a sentiment or patriotic effort by a people belonging to the same ethnological family, speaking the same language, under the same government and inhabiting the same country". According to this definition, nationalism must be a sentiment or patriotic effort based on similarity in respect of (a) ethnicity, (b) language, (c) polity, and (d) territory. The lack of any one 
of these elements will not connote the completion of the meaning of the term "nationalism"; rather such a construct could be termed "convenient nationalism" or "nationalism of convenience"-more like a marriage of convenience, where some of the factors constituting the essentials of nationalism are brought into a convenient fusion to achieve a particular objective.

There are various theories dealing with the phenomenon of nationalism. Their variations, however, are subject to spacio-temporal limitations giving rise to two broad categories: (a) the enumerative theory of nationalism and (b) the idealistic and subjective theory of nationalism. In both these categories the position of religion in nation building efforts is not neglected - although the degree of religious involvement in them is rather circumspect. It is the case that from religion arose national customs, traditions and folklore of great significance, which wielded a powerful influence in fashioning national feeling. The religion of individuals subsequently, became the national or state religion. However, the general trend prevalent in the contemporary world is to move away from the interdependence of nationality and religion. The main religions of mankind nowadays claim universality, and claim to preach one god and brotherhood of humans. Therefore, religion is bound to come into conflict with the essentially exclusive and pluralistic sentiment of nationality. A secular national code of values is fashioned to judge everything from the point of view of the well-being of the nation. The success and progress of the nation will depend to some degree on the extent to which it can force religion, notwithstanding its universal character, to fit into the national mold and serve national ends. It is this classic struggle to fit religion into the mould of national politics that brings nationalism into direct confrontation with Islam. In strict Qur'anic teachings, the Qur'an addresses the entire creation and all humanity of diverse nations as one ummah occupying the territory of the earth, speaking the language of God and conducting their lives knowingly or unknowingly in accordance with Divine rules.

If nationalism is defined as "devotion to one's nation", it does not follow that this devotion requires complete disregard of other factors such as ethnic-race and religion which often blend together into the concept of a 'nation-state'. There is a need to interpret the Islamic terms millah and ummah in their narrower sense as 'community' rather than as 'nation-state'. If not, this will bring Muslims into conflict with the principles of nationalism, and result in creating a state within a state. Islam is not against accommodative nationalism - but explicitly recognises such a concept of nationalism, for the Qur'an states, "We made you into tribes and nations so that you may understand one another". ${ }^{12}$

Integration is simply defined as absorption into an existing whole. In a more profound sense it means to end racial segregation by giving full and equal membership within the larger group or in a society. Integration is the process of 
making into a whole, or the unification of all elements in a society. Unification does not necessarily lead to uniformity in everything such that one has to forgo one's own distinctive identity and become blended into the whole. This is not possible anywhere in the universe, for the universe itself is made up of diverse planets, stars and constellations of varying constitutions, characters, functions and configurations, yet they function in an integrated way whereby each planet, star and constellation serve magnificently the overall purpose of the universe. So there is overall unity of purpose within particualar diversities. Similarly within a country, the existence of diverse ethnic and religious groupings with varying beliefs, traditions and values need not create conflict. Rather they may magnify the diversified richness of that nation. Yet this diversity should not be allowed to result in any ethnic group being relegated exclusively to a specific social status in the larger national structure, e.g. as typified by the Hindu caste system, since only when groups are allowed to blend equitably together in the common space may they form a greater meaningful integration.

In other words integration in no way requires one to lose one's own distinctive identity in order to gain membership, even though there always are certain prerequisites for seeking any membership. It is these prerequisites which need to be scrutinised in respect of Muslim participation in their nation's development and solidarity. Integration in one respect requires disintegration in another respect. With respect to nationalism, integration may induce disintegration to a certain degree viz-a-viz religion, race, or culture, and vice-versa. Thus it is very difficult for both to coexist exclusively in one political entity without some degree of deliberate flexibility and accommodation. This is precisely the dilemma Muslims in minority settings face, which may also affect Muslims in certain Muslim majority countries as well.

In the view of Gani, national integration "implies a sense of belonging, a feeling of togetherness, of unity". ${ }^{13}$ It requires creating a social and religious climate in the country wherein all its citizens, irrespective of their religion or their social status, may live a life of peace and tranquility devoted entirely to the common purpose of building a strong and united country. ${ }^{14}$ So national integration signifies "a condition of unity in diversity in which all components are equally valued and interdependent". ${ }^{15}$ Any meaningful discussion on such integration must take into account both unity and diversity, for if there is only unity then integration is not necessary, and if there is only diversity, then integration is not possible. ${ }^{16}$ Integration does not mean transforming diversity into uniformityrather the process of national integration denotes the congruence of diversities leading to a unity in which all the varieties and peculiarities are preserved. ${ }^{17}$

Freedom: It is necessary to understand the exact import of the term "freedom" as understood by liberals, 'Freedom' is alien to Islam, for they aspire to an 
absolute freedom which is bereft of any divine guidance and/or moral restraints. Absolute freedom belongs logically only to God since He is the Absolute, Who is not answerable to anyone. Thus, freedom in Islam refers to human ability to become, rather than human ability to act. In the opinion of Islamic jurists human freedom refers to man's "personal surrender to the Divine Will". ${ }^{18}$ Now it is understood that the moment a person surrenders himself either willingly or unwillingly he loses something of his freedom. His ability to act freely has been somewhat curtailed, however he still retains his freedom in respect of his ability to become what he wishes to be. It is in exercising this freedom that man chooses to be either a Muslim or a non-Muslim. The moment he becomes a Muslim and begins to act accordingly he thereby conforms to and confines himself to the rules and regulations of Islam, which specifically restrain his freedom to become a non-Muslim after having been maturely a Muslim.

Religious freedom is a crucial pivot in minority-majority interactions. Every country speaks of granting religious freedom to minorities as one of their rights. However, in actual practice such freedom is generally restricted. The freedom that is in line with human dignity is a wholistic one that guarantees both [a] a "freedom from" and $[\mathrm{b}] \mathrm{a}$ "freedom to". That is, a freedom from injustice and inequality as well as a freedom to express their values, cultures, their higher creative potentials as well as their responsibilities to one another. Many think that freedom refers only to [a] but consider $[\mathrm{b}]$ as a threat. When confronted with hostility and racism in non-Muslim countries, Muslims in those countries are forced to turn to their faith for support and reaffirmation of their identity. But this "going back to their roots" or reactive turning to one's faith is often mistakenly taken as a threat to national integration. Increasing hostility both in the media and public towards ethnic minorities, especially Muslim minorities, leads to a polarisation of racial issues which affects the peace and security of the particular nation. Any feelings of hopelessness and despair amongst minority youth can precipitate aggressiveness and militancy, becoming targeted by extremist groups who seek to channel negative energies to commit acts of violence. It is imperative especially in these difficult times to have "an open mind, acceptance of other cultures, respect for one's traditions, and the belief in the shared destiny of human kind." 19 This is true for both the non-Muslim majority, and for the Muslim majority towards their non-Muslim minority.

Equality: Muslims and non-Muslims should ideally have equal rights and obligations in any country, which means that both Muslims and non-Muslims can vote, be members of government, ministers, judges, officers in the armed forces, and may reach top positions. Great Muslim polities historically have been known to aspire to a practical application of this ideal. In practice, however, this may not be exemplified in our modern era, or cannot be fully implemented 
in countries where inequalities already existed and social reform needs to be undertaken in the interim period to create a level playing field through affirmative action programs. Similarly Muslim minority countries should state clearly their real agenda for their Muslim citizens. Discriminatory laws and practices should not be imposed in the name of national security, nor should the true loyalty of Muslims be conveniently doubted just to shirk their basic obligations towards their Muslim minority. According to Fathi Osman,

A majority cannot deny a minority its rights, on the grounds that a minority has to respect the rights of the majority to have their state system. Unless the state system secures human rights for all citizens without discrimination, it would encourage contradictions and disputes within the country and would lose world support. Furthermore, any discrimination against a Muslim minority in a non-Muslim country cannot be strongly opposed universally if a similar injustice is committed by Muslims against non-Muslim minorities. Whatever the 'nicety' in human relations may be in daily life, 'equality' has to be secured and sanctioned by law. ${ }^{20}$

Pluralism or the principle that people of diverse races, religions, and political beliefs can live together peacefully in the same society- a so-called modern phenomena - is not something new at all to Islam. Islam itself came into existence in such a primordial pluralist society. Haddad observes that pluralism as a foundational principle of nature is evident in the revelation of the Qur'an where all humanity is treated equally. ${ }^{21}$ There is no distinction in color, language, rights, or lineage, and all are equal before the law. Nevertheless, minority Muslims are discriminated against by not being able to live under what passes for pluralism in that country. What appears to be occuring under the name of pluralism is a value-nihilism and a steady erosion of cultural distinction between communities. There is nothing wrong in supporting even this dubious pluralism, provided it accords each community the freedom to function according to their religiocultural norms. This definitely would add diversity and color to the society and strenghthen bonds between the various communities, since they may each understand and tolerate, if not also respect, their differences.

\section{General Sociological Framework for Minority-Majority Relations}

A majority's policies and its attitude towards minorities may range from peaceful assimilation to extermination. In their topology, Simpson and Yinger present the following six varieties of policy which the majority develop towards the minority: ${ }^{22}$ Assimilation, Pluralism, Legal protection, Population transfer, Subjugation, and Extermination. Assimilation is not achieved through coercion 
nor by a majority adopting an extreme ethnocentrism and refusing the minority the right to practice their own religion or follow their own customs. On the contrary, peaceful assimilation may encourage a minority to adopt and adapt some patterns of the majority culture in their own way and at their own pace, perhaps beginning with material interests and progressing gradually towards cultural and spiritual assimilation.

In a pluralist society the majority may moderate the cultural variability within the basic doctrines of the people and the security of the nation. These cultural differences are overshadowed by a strong political and economic necessity and unity, which necessitates the elimination of nationalism based on mono-cultural ideals. To achieve this equilibrium the majority must compromise its cultural dominance and superiority, while the minority must forgo its desire for political and economic separation, since the success of this cultural pluralism depends on the degree of reduction in respect of tension and discrimination. Legal protection of the minority arises when the majority refuses to accept this reality. It is precisely due to this refusal by a majority state, that the minority has to seek international intervention to guarantee the respect of their rights. The majority at times attempts to reduce minority problems through enforcing a policy of population transfer whereby the minority are physically separated or scattered throughout the land.

In case the majority intends not to integrate the minority either through assimilation or pluralism, nor even by population transfer, there arise two other methods, namely subjugation and extermination, which in contemporary parlance are known simply as ethnic cleansing. These six approaches or policies adopted by the majority to regulate the problem of integrating their minority are not mutually exclusive, since they can be applied sequentially or simultaneously. Furthermore, these six policies have been customised and fine-tuned over the years to the extent that they no longer remain in their original mould. Elaborating on the phenomena of the minority, Louis Writh observes: ${ }^{23}$

If a group sets itself apart from others by a distinctive culture and perpetuates itself in this isolated condition long enough, the social distances between itself and others may grow so great as to lead to the accumulation of suspicion, and to non-intercourse which will make it virtually impossible for members of these groups to carry on a truly collective life.

Therefore, any lack of closer contact with or intimate knowledge of other groups, particularly in majority-minority relationships, may hinder the capacity to understand and appreciate one another, which in turn leads to mutually hostile stereotypes. Thus, the minorities must pattern their behavior according to their objective position. 
Treating how Muslim minorities develop, Khalid M. Ishaq states they follow the following patterns: ${ }^{24}$

(a) A community is reduced to ineffectivity despite its numerical majority because of non-Muslim occupation. The majority is then transformed into numerical minority through large-scale expulsion or through unfriendly policies.

(b) When Muslim rule in a land does not last long enough, or the efforts to propagate Islam are not vigorous or effective enough to transform the Muslims into a numerical majority in the lands which they rule... With the collapse of the political power of the Muslims they find themselves reduced to the status of minority in their own country.

(c) Through the conversion of a certain number of non-Muslims in a nonMuslim environment.

(d) Migration of Muslims to non-Muslim countries in search of opportunity or security from oppression in their homeland.

(e) Forced migration of Muslims to non-Muslim countries as refugees.

Thus it is evident that despite the nature of their minority status, Muslims have to adjust to the prevailing socio-cultural currents for their very survival. In the above pattern there is an order of plight where the situation of Muslims falling under [a] and [b] is worse. The non-Muslim majorities work to ensure that Muslims in these situations are kept at the lower rung of society. In pursuit of these social engineering policies, some countries under situations [a] and [b] are breeding their own Muslim leaderships drawn from the periphery of the community (not mainstream Muslims). These Muslim leaders are converts to Islam and are connected or related directly or indirectly to the existing status quo (albeit non-Muslim majority) through blood relations or they are professionally, commercially or even maritally linked. Such political manoeuvres are employed not only to undermine genuine Muslim leaders who traditionally command international support and sympathy, but eventually could lead to hijacking their leadership of the community in order to gain access to international Muslim bodies and institutions. Conversion in this sense is being abused as a convenient tool to pursue the agenda of those who want to remain as a dominant power.

\section{The Muslim Dilemma: A Study of Muslim Minority Situations}

In early Islamic jurisprudence the world was categorised into (a) Dār al-Islām (comprising Islamic and non-Muslim states held under Muslim rule) and (b) Dār al-Harb (literally a territory of war). ${ }^{25}$ Surprisingly there is no indication for such a theory in either the Qur'an or the hadīth. Perhaps Islam sees no relevance in such a distinction, since it is a message for the entire universe. This was a juridical development when the Islamic Empire reached its territorial extent and 
the jurists were working on the matrix of incorporating the many cultural and ethnic groups thriving therein. In this process of assimilation the jurists differed in their definition of Dār al-Islām, for Islamic law binds an individual to the community to which he belongs and not to the territory in which he resides. Tamara Sonn in her Islam and the question of Minorities observes:

Whether one agrees or not that Islamic tradition overall needs significant rethinking, there are some areas in which it is clearly necessary. Those are the areas not specifically dealt with in the classical codes. Islamic law was codified by and for Muslims living in a predominantly Muslim world. That world was identified, in fact, as dar al-islam, the "abode of Islam" ... [which] was distinguished from dar al- 'ahd, the "abode of covenant", dar al-sulh, the "abode of truce", and dar al-harb, the "abode of war". It referred specifically to those territories in which the law of Islam prevailed, a situation that was possible only because the vast majority of the population was Muslim. Dar al-'ahd and dar alsulh were both regions whose leaders had agreed to pay the Muslim leaders a certain tax and to protect the rights of any Muslims and/or their allies who dwelt there, but who otherwise maintained their autonomy, including their own legal systems; dar al-harb was a region whose leaders had made no such agreement and where, therefore, Muslims and their allies, unprotected by law, were technically under threat. ${ }^{26}$

Even though this classification now appears to be defunct, it nevertheless raises significant questions about the identity and status of Muslim communities in different locales, and now shifted from predicating it upon a legal system specific to a religious community to a nation state wherein laws based on truths about all human beings which are assumed to be self-evident with human rights assumed to be universal.

"Islam" states Fazlur Rahman, "like Communism, insists on assumption of political power, as the will of God has to be worked on earth by a political system". ${ }^{27}$ According to J.H. Kramers, "The only political unity of Islam was the ideological but powerful concept of Dar al-Islam, the common homeland of all Muslims". ${ }^{28}$ Islam takes a pragmatic approach to these questions since it has not laid down any clear-cut rules and regulations. This is understandable, for most Muslims aspire to live in a Muslim majority, if not also Islamic, country run by a government which ideally implements the full range and force of the shari ${ }^{-} a h$. All political theories based on the shari 'ah provide detailed rules for the functioning of such a government. The sharī'ah provisions for Muslims living as a minority, however, are not sufficiently adequate to accommodate all the contingencies that exist outside the realm of a Muslim state. 
The situation of Muslims living as minorities in non-Muslim countries poses difficulties regarding their position and status within the ambit of the global Islamic community. Are Muslims required to live only in a Muslim state? Is shari 'ah applicable in a non-Muslim environment? If so what aspects of the shari' $a h$ are applicable in a non-Muslim setting? These are some of the questions confronting Muslims in those countries where they happen to constitute a minority. We now present various scenarios wherein Muslims experience a minority situation.

\section{Scenario 1: Muslim Minority in a Single-Ethnic Country ${ }^{29}$}

The situation of Muslims living as a minority in countries like Germany, France, Italy, Denmark, Norway, Sweden, Netherlands, Japan, Korea could be grouped under this category. These countries and their likes represent countries with one single ethnic majority regardless of the differences it has with its sub-ethnic brethren in terms of dialects or religion. It is understandable for these single ethnic nations to press for integration, in order to safeguard and promote their cultural values. Since these countries represent the origins of their respective ethnicity, it is quite natural for them to strive to impose their values on others, particularly on those who migrated to these countries. Explaining the reasons for such severe reactions, Abdul Hadi Hoffmann states: ${ }^{30}$

For one thing, some Germans feel those who reject their inherited religious tradition are traitors somehow. More importantly the existence of Muslims of ethnic German origin also deprives the opponents of Islam of their basic argument: that Islam is foreign to Germany. It is easy to avoid dealing with the message of Islam when you are culturally distinct from its adherents. Differences in language and eating habits, it seems, act as a buffer between ethnic Germans and immigrant Muslims, allowing the former to maintain their conviction that Islam does not belong on German soil. But there are no such shields when these people confront Muslims who are ethnic Germans. Finally, German Muslims know their rights as citizens. They know the political framework and to how to work within to demand their rights. It is to be expected that they are much more determined to fight for their rights and enter the political field. Perhaps this appears to xenophobic Germans as a far more dangerous threat even than the "foreigners" for, in fact, joining the political fray is just what German Muslims have begun to do.

There are many practical reasons and barriers against the incorporation of Islam into German society. First, like many other nations of the West, Germany is considered a secular state with deep-rooted enlightenment as its ideal. However, 
this assertion is not necessarily accurate, particularly when the relation of the state with the church is examined. Even though a clear distinction is drawn to keep the church out of the political domain, the cross-representation of the interests of both the political and religious institutions, happens when they choose to teach Christian religious instruction as part of the religious curricula in national schools. Therefore, in spite of secular over-tones, there is a strong public Christian presence in Germany. Secondly, the 1400 years of Christian teachings, particularly their opinions on Muslims, have shaped the German mind. These writings, as Hoffmann argues, reflect ignorance of Islam and at times "a distinct anti-Islamic bias". ${ }^{31}$ Moreover, the spirit of the crusades still haunts the minds of many Germans and stands "in the way of appreciation of the contributions of Islam to world history". ${ }^{32}$

\section{Scenario 2: Muslim Minority in a Multi-ethnic Country}

This refers to the situation of Muslims in countries which came into existence as a result of post-colonial dispensations, direct or indirect, that are geared to serve their perceived interests, such as Israel and Singapore where the population consists of dominant numbers of migrants and where creating a nation out of one particular ethnicity. ${ }^{33}$ In the case of Israel which is a by-product of European colonial domination over a Muslim region, the situation of Muslims is somewhat complex, since there are Muslims living in Israel itself whilst their own brethren living in the occupied Palestinian enclaves of West Bank and Gaza are subjected to purges, attacks and invasions by the Israeli military.

In the past, there is a tendency to compare Singapore with Israel due to a number of striking similarities. The two regions were considered allies of the superpowers representing Anglo-American interests, and as such their survival is guaranteed even at the expense of their respective Muslim neighbors. Any developments in these respective regions by the Western powers will be based on the continued security and prosperity of these two countries. The real situation of Muslims in both these countries, however, varies significantly even though the underlying attitude towards Muslims therein still remains constant. In the case of Israel, ever since its creation media reports highlight the systematic oppression and dispossession of Palestinians who are systematically purged from socio-economic institutions. The state of Israel has over the years unleashed colossal human disasters upon the Palestinians. However, despite this atrocious record the Palestinian natives are given their special institutions like shari 'ah courts for Muslims. ${ }^{34}$ From a clearly avowed anti-Islamic state like Israel, this institutional concession to Muslim needs is laudable and indeed perplexing. Meanwhile, in Singapore which has promoted itself as a Muslim-tolerant 
country, the government has been more than accommodative of the Muslim minority. Muslims there do have a sharī'ah court, an Islamic religious council, a registry of Muslim marriages and a score of "independent" state-approved Muslim organisations to cater to the various religious and social needs of the Muslims. There is no shortage of Muslim organisations. But there exist powerful anti-Islamic forces ${ }^{35}$ which have been creating problems for Islam and Muslims $v i s$-à-vis national life and governance. The government has adopted peaceful and sincere, albeit reluctant efforts to bring Muslims into the national mainstream and thereby to showcase to the world the accommodative model Singapore has adopted in systematically integrating its diverse ethnic and religious population, through a prolonged process of deliberate, seemingly benign, social engineering. Commenting on this daring social engineering Kuo Pao Kun observes [Emphasis added],

In the 40 years of Singapore's thorough transformation, the government has been singularly subversive of old systems and practices, as it has been boldly innovative in devising new methods and ideas. In resettling the bulk of the population, neighbourhood was totally recast; social networks were completely rebuilt, with government agencies replacing the former grassroots networks. In the new scheme, the government and its agencies dictated policy and management in almost every aspect of community life. Racial peace, in effect, was managed by the state. Restrained and contained, the people lived safely under constant government protection and surveillance. ${ }^{36}$

The real concern here is that the sincere efforts of the government will all simply go to waste if such anti-Islamic extremists in its own folds are not equally and systematically checked, engineered or weeded out.

\section{Scenario 3: Muslim Minority in a "Secular" Heartland}

There is no other country on earth which can be considered as a safer haven for secularism than India. With its multitude of racial, ethnic, linguistic and religious colors India represents the "secular paradise" on earth. Ever since her independence, the social tranquility of this earthly paradise has been put to test by forces working against her peace. These forces are, usually, not from outside, but are well entrenched within her borders. It is these forces which are responsible for more than five hundred racial and religious riots annually involving mainly, though not always, Muslims, with them often at the receiving end. The plight of Muslims has worsened as there is a deliberate attempt to punish, for starters, the Muslims and to deprive them of their status as respectable citizens in an India, perhaps, 
misleadingly touted as a model for secularism. Lamenting on the paradoxical and tragic situation of Muslims in India, Harman insightfully comments:

The plight of Indian Muslims is greater than that of Catholics in Northern Ireland, because the Catholics in Ulster can hope to get their grievances redressed and to improve their position by obtaining political concessions. Muslims can't look forward to any such relief because they already have fullest political rights. The sorrow of Indian Muslims is greater than that of ... the Palestinians because there are definite proposals which if accepted and implemented can solve their problems. Indian Muslims have no such solution in sight ... The difficulties of Indian Muslims are greater than those of Muslim minorities in other countries, since in those countries the culture and way of life of Muslims is not different from that of the main body of the people. In the case of Indian Muslims their life follows a course fundamentally different from the national mainstream. ${ }^{37}$

\section{Scenario 4: Muslim Minority in Socialist Countries ${ }^{38}$}

In comparison to the Muslim situation in democratic and capitalist India, Muslims in China and even those in Russia and Newly Independent States are living in relative peace and with greater dignity. The decades of ruthless authoritarian and communistic rule did not change the resolve of Muslims to preserve and uphold their religious identity. Even though the practice of Islam in these socialist countries was heavily censured during their communist era, the winds of change after the collapse of the Soviet Union has brought in renewed hope for Muslims to live out their re-acquired religious freedom.

While relative freedom has long been relished by Muslims in China, the Muslims in several parts of even Muslim autonomous areas and republics in the dissolved Soviet space are once again suppressed with iron hands reminding them afresh of the harsh realities of the communist era. With reference to the appalling situation in Russian occupied Chechnya De Waal states that "The Moscow leadership is incapable of total repression of Chechnya, even if it wanted to ... sooner or later, for its own pragmatic reasons, if no other, it will have to start heeding the voice of the suffering Chechen majority". ${ }^{39}$ Therefore, the authorities in these polities must realise that no amount of shortsighted pressure and violence will quell the politico-religious awakening of the population. Attempts, instead, must be made to win the hearts and minds of the people; otherwise, incidents like Beslan may remain precursors to bloodier tragedies awaiting to happen that may once again claim totally innocent lives. 


\section{Scenario 5: Muslim Minority in a 'Free Country'40}

The United States as an advanced country is considered the role model for ensuring a wide variety of freedoms, for welcoming and respecting peoples of all kinds of religious and cultural persuasions and for continually upholding democratic principles. An American is free to engage in any activity which does not undermine the interests of his country. The world is witness to the United States' unilateral undertakings in a number of world regions and conflicts, which baffles Muslims regarding the agenda America proposes to pursue. Very much within this agenda is the situation of an ever-expanding American Muslim population. The question for Muslims in America now is how does the U.S. government define its interest, and what is the position of the government vis-àvis Islam and Muslims? There seems to be no consistency in its policy of pursuing its vital strategic interests.

Nationalism as defined above would narrowly exclude both America and Islam as epitomes of nationalism. For Islam is not confined to any particular ethnicity or language or a nation based on either. In the case of America itself, it is not made of one particular ethnic group called Americans. What we see in this great country is, a melting pot of all peoples, cultures and religions. In this respect America has some semblance to Islam in the sense that it easily accommodates a wide variety of distinct peoples and cultures of different parts of the world. Can there then be any conflict in being a Muslim and an American together? The answer is a clear no. Difficulty, however arises when one is asked is she/ he a Muslim American or is she/he an American Muslim. There should be no surprise in finding Muslim individuals, groups, organisations and yes, states at the opposite end of the spectrum in this respect. In fact the basis for this allegedly controversial stand can be traced to two hadiths wherein the blessed Prophet is reported to have said:

(a) "Al-Islam ya 'lu wa la yu 'la 'alayh [Islam will surpass and will not be surpassed]" 4 .

(b) "hubb al-watan min al-iman [to love one's nation is part of faith]"42.

Those who hold that Islam should be given preponderance over politics, base their stand on (a), while those who hold that politics should be given preponderance, base their stand on (b). In our opinion both are right in their respective contexts. According to (a) a Muslim should consider himself a Muslim first and then as an American, as opposed to (b) which gives relative importance to nationalism. The difficulty arises, however, when grouping America's multiethnic Muslim population under one banner called Muslim Americans, for there is no uniformity among them in respect of even their religious observations. As 
long as Muslims in America continue to stay divided in respect of their racial and linguistic orientations, not to mention in their religious practice, the vision of a Muslim American cannot be achieved. It is mandatory that Muslims must begin to take an active participation in all aspects of American society, whereby they will act as catalysts for positive change.

To impose any restriction on Muslims' observance of their religious duties or to use that as a pretext to discriminate against them runs against the very constitutional provisions of America, wherein religious freedom has been explicitly guaranteed. Just because one religion finds peace by avoiding public display of its religious belief, ought not necessarily mean that the same principle should be applied to all other religions; while in Islam such open public display may be mandatory. If one's faith has to follow reluctantly the principles of the ruling faith which are in contradiction, then one has to question the definition of freedom in American parlance, and all which undermines the position of religion in that society. A Muslim must be allowed to practice the shari 'ah, in America, even in respect of his marriage and inheritance. The imposition of American law in place of the relevant Islamic provision has caused many inconveniences for Muslim Americans. The fact that Islamic marriages are not recognised as lawful marriages and requiring couples to go through a civil procedure in addition, violates both American freedom and Islam. America should show a certain degree of flexibility in this respect. However, there are non-Muslim countries where Muslims are given this special arrangement within their legal structure. For example Muslims in Israel, Singapore and the Philippines are enjoying this facility.

Muslims in America must actively participate in the nation building of America. In particular, they should act as catalyst for socio-economic reforms which benefit American society as a whole. In dealing with such an undertaking Muslims in America must put the interests of American reforms first and explore ways and means by which Islamic principles can also be observed under those reforms. When it comes to the security of America, every Muslim American must give it their top priority, even if it means, at times, going against the interests of their own brothers in faith elsewhere. ${ }^{43}$ However they have first to ensure that the cause they struggle for is justified and morally right and not simply fall into the snares of political or economic expediency.

\section{Recommendations}

- It is recommended that in order to contain and manage the dilemma faced by minority Muslims, nations must improve the general physical living conditions and basic material welfare of their citizens irrespective of their creedthrough undertaking health, education and socio-economic infrastructural and manpower developments. By so doing the exodus of Muslims to non-Muslim 
countries in pursuit of material gains and general betterment will be drastically reduced and the pool of minorities and their consequent miseries overseas too would similarly be reduced.

- It is also recommended that Muslim majority countries and in particular their governments must begin to view their human resources as assets to be consolidated and treasured, and not as liabilities to be liquidated and disposed of - as one country's liability could easily be another's asset. Efforts must therefore be made to improve the basic political dynamics of their societies through a process of increasing democratisation, and according greater freedoms within the framework of the shari' $a h$. There is a need these days to continually reconcile the sacred principles of sharì'ah within evolving realities.

- Muslim majorities should first be able to see readily, witness and sample justice delivered to them under the principles of shari' 'ah in their own countries. When the physical, legal, material and spiritual situations of Muslims in Muslimmajority countries are thus improved, it will give them the moral strength to voice concerns regarding the situation of Muslims in minority countries and responsibly back this up with material strength. They could link trade agreements and other economic opportunities between them and non-Muslim countries with the degree of rights that non-Muslim states accord to their Muslim minorities. Muslim-majority countries must develop the necessary templates to ascertain and ensure noble objectives are accountably achieved.

- Muslims in minority countries must also play their responsible roles as citizens of their own countries especially if they have secured all the rights due to citizens and do not as a community feel blatantly discriminated against. However, several non-Muslim countries have clearly ignored and violated the basic rights accorded to their citizens upheld by the UDHR by keeping their Muslim minority as an underclass. This does not mean that minority Muslims should partake in unjust war of attrition against fellow Muslim countries. They must not hesitate to responsibly and properly take to task their own governments when and if they believe that they have been misled into believing that their forces are in Muslim lands to liberate Muslims from the tyranny of their past. The post-9/11 world has helped to highlight the plight of targeted Muslim majorities and increasingly pressurised the minority Muslims to exercise their responsibility as citizens of their respective countries and as citizens of the ummah to play mediatory roles in conflicts between the Muslim and non-Muslim worlds. This is a challenging task for which the Muslims are as yet ill-prepared. 


\section{Notes}

* Hikmatullah Babu Sahib is an Assistant Professor in the Dept. of General Studies, International Islamic University Malaysia. Email: hikmatullah@iium.edu.my

** Asiah Binti Yaacob is an Assistant Professor in the Department of Qur'an and Sunnah Studies, International Islamic University Malaysia. Email: asiahy@iium.edu.my

1. Rashid Ahmad Jullundhri, "Human Rights and Islam", in Understanding Human Rights: An Interdisciplinary and Interfaith Study, ed. Alan D. Falconer (Dublin: Irish School of Ecumenics, 1980), p. 34.

2. Ibid.

3. Ibnul Hasan, "Muslim Minorities: A Profile", in The Changing World of Islam, ed. Jameel Jalabi and Kazi A. Kadir (Karachi: University of Karachi, 1986), p. 122.

4. Longman Dictionary of Contemporary English, New $3^{\text {rd }}$ Edition (Essex: Addison Wesley Longman Limited, 1995), p. 904.

5. Tabandeh, Sultanhussein, A Muslim Commentary on the Universal Declaration of Human Rights, trans. by F. J. Goulding, (United Kingdom: F. T. Goulding \& Co. Ltd., 1970), p. 85.

6. Ibid.

7. Jullundhri, op.cit., p. 35 .

8. Abdul Aziz Said, "Human Rights in Islamic Perspective", in Human Rights: Cultural and Ideological Perspectives, eds. Adamantia Pollis and Peter Schwab (New York: Praeger Publications, 1979), p. 86.

9. Tabandeh, op.cit., p. 70

10. Ibid.

11. Fathi Osman, 'Islam and Human Rights: The Challenge to Muslims and the World' in El-Affendi, Abdelwahab, (ed.) Rethinking Islam and Modernity: Essays in Honour of Fathi Osman (London: The Islamic Foundation, 2001), p. 32.

12. al-Qur'an 49:13

13. H. A. Gani, Muslim Political Issues and National Integration (New Delhi: Sterling Publishers Pvt. Ltd., 1978), p. 2.

14. Ibid.

15. Ibid.

16. Ibid., pp. 2-3.

17. Ibid., p. 3.

18. Abdul Aziz Said and Jamil Nasser, "The Use and Abuse of Democracy in Islam", in International Human Rights: Contemporary Issues, eds. Jack L. Nelson and Vera M. Green, (New York: Human Rights Publishing Groups, Earl M. Coleman, 1980), pp. 76-7.

19. Bashy Quraishy, "Multi-culturalism... - threat or enrichment?" in Djembe, no. 25, July 1998. For details, see: http://www.djembe.dk/no/25/20mcawt.html

20. Osman, op.cit., p. 49.

21. Yvonne Yazbeck Haddad, Islamists and the Challenge of Pluralism, Occasional Paper of Centre for Muslim-Christian Understanding (George Washington University, 1994), p. 6.

22. G. E. Simpson, and J. M. Yinger, Racial and cultural minorities: An analysis of prejudice and discrimination (New York: Harper, 1958), p. 27.

23. L. Writh, "The Problem of Minority Groups" in Ralph Linton (ed.), The Science of Man in the World Crisis (New York: Columbia University Press, 1945), p. 350.

24. Khalid M. Ishaq, "Evolution of Human Rights in the West and its Implications for Muslims", in Muslim Communities in Non-Muslim States (London: Islamic Council of Europe, April 1980); cited by Ibnul Hasan, op cit. pp. 122-4.

25. See on these concepts Majid Khadduri, "The Islamic theory of international 
relations", in J. Harris Proctor (ed.) Islam and International Relations (New York: Praeger, 1965), pp. 24-39.

26. Tamara Sonn, "Introduction", in Tamara Sonn (ed.) Islam and the Questions of Minorities (Atlanta, Georgia: Scholars Press, 1996), pp. 2-3.

27. Fazlur Rahman, Islam (New York: Anchor, 1968), Introduction.

28. J.H. Kramers, "Address" in Proceedings of the XXII International Congress of Orientalists (Istanbul: 1953), p. 94.

29. For situation of Muslims in Europe see Yvonne Yazbeck Haddad, ed., Muslims in the West: From Sojourners to Citizens, (New York: Oxford University Press, 2002), pp. 3-166.

30. Abdul Hadi Hoffmann, "Muslims in Germany: the struggle for integration", in Tamara Sonn (ed.) Islam and the Questions of Minorities (Atlanta, Georgia: Scholars Press, 1996), pp. 46-7.

31. Ibid., p. 51.

32. Ibid.

33. For discussion on how Muslim Majority Singapore became a Muslim Minority Singapore, see Husain Haikal and Atiku Garba Yahaya, "Muslims in Singapore: The Colonial Legacy and the Making of Minority", Journal of Muslim Minority Affairs, vol. 17, no. 1 (1997) p. 84.

34. R. H. Eisenman, Islamic Law in Palestine and Israel: A History of the Survival of Tanzimat and Shari'a in the British Mandate and the Jewish State, (Leiden: E.J. Brill, 1978).

35. There is a need to qualify the term "anti-Islamic forces", lest readers mistakenly conclude this term refers exclusively to non-Muslim groups. Certainly, there are many Islamophile non-Muslims, as opposed to the phenomenon of increasing numbers of Islamophobic Muslims. It is these opportunity-seeking Muslims who pose the greatest threat to the cause of Islam, with the encouragement and empowerment of the sworn enemies of Islam. Sadly, such misguided Muslims willfully trade Islam for personal gain by engaging in all manner of activities repugnant to the teachings of Islam.

36. "Contemplating an Open Culture: Tanscending Multiracialism" in Singapore: Re-engineering Success, ed. Arun Mahizhnan and Lee Tsao Yuan (Singapore: Oxford University Press, 1998), pp. 52-3. Emphasis added by this writer.

37. S. Harman, Plight of Muslims in India (London: DL Publications, 1977), p. 155.

38. For an overview of the situation of Muslims in Socialist countries, particularly China and the Soviet Union see, John O. Voll, "Muslim Minority Alternatives: Implications of Muslim Experiences in China and the Soviet Union", Journal of the Institute of Muslim Minority Affairs, vol. 6 (July 1985), no. 2, pp 332-53.

39. Thomas De Waal, "A Journalist reflects on the two wars in Chechnya", Central Asian Survey (December, 2003) 22/4 p. 468.

40. For situation of Muslims in the U.S.A. see Y. Haddad, Muslims in the West, pp. 169-261.

41. Jalāl al-Dīn Al-Suyūțī, Al-Jāmi ‘ al-saghīr fì ahädìth al-bashīr al-nadhīr, $4^{\text {th }}$ ed. (Singapore: Matābi' Sulaymān Mar'ī, n.d.), vol. 1, p. 123.

42. For discussion on this hadìth, see Ismā'îl b Muhammad al-'Ajlūnī, Kashf alkhafā' wa-muzīl al-ilbās 'ammā ishtahara min al-ahādìth 'alā alsinat al-nās, $3^{\text {rd }}$ ed. (Beirut: Dār Ihyā̄' al-Turāth al-'Arabī, 1351 H.), vol. 1, pp. 345-6, no. 1102.

43. According to Doi, "Muslim soldiers will have to show their loyalty to their own countries even if it is a non-Muslim state fighting against a Muslim state". See Abdur Rehman Doi, "Duties and Responsibilities of Muslims in Non-Muslim States: A Point of View, in Journal of Institute of Muslim Minority Affairs, vol. 8: 1 (Jan. 1987), p. 52. 